\title{
Effects of group size and space allocation on physiological, behavioural and production-related welfare parameters in farmed silver fox cubs
}

\author{
Leena Ahola, Jaakko Mononen, Teija Pyykönen, Maarit Mohaibes \\ Institute of Applied Biotechnology, University of Kuopio, PO Box 1627, FIN-70211 Kuopio, Finland, \\ e-mail: leena.ahola@uku.fi \\ Teppo Rekilä \\ MTT Agrifood Research Finland, Animal Production Research, FIN-69100 Kannus, Finland
}

\begin{abstract}
Traditionally farmed silver fox cubs are raised after weaning either in pairs or singly in a traditional fox cage $\left(1.2 \mathrm{~m}^{2}\right)$. However, this way of housing foxes has been criticised because the foxes may have limited chance to exercise and to show social behaviour. Therefore, the aim of the present study was to evaluate the effects of different social and spatial conditions on the welfare of silver fox cubs. The cubs were housed singly, in pairs or in quartets with space allocation of either 0.6 or $1.2 \mathrm{~m}^{2}$ per animal. Behavioural, physiological and production-related welfare parameters were assessed. The results revealed that space allocation had only minor effects on the measured welfare related parameters. With regard to social conditions, the results showed that the possibility for social behaviour is important for the welfare of young cubs. However, the welfare of the cubs may be jeopardised if they are kept in quartets beyond their natural dispersal time. Therefore, the welfare of silver fox cubs could be enhanced by allowing the cubs to enjoy of social companionship during the first months of their lives and by separating them into pairs in later autumn.
\end{abstract}

Key words: animal welfare, behaviour, fur farming, group size, physiology, space allocation, Vulpes vulpes

\section{Introduction}

One of the most efficient ways to enrich the environment of farmed animals is to increase animals' possibilities for social behaviour (see Mendl and Newberry 1997). This beneficial role of social enrichment might be presumed to be in agreement also with farmed silver foxes (Vulpes vulpes): although in nature red foxes (Vulpes vulpes) have been viewed as rather solitary (see Cavallini 1996), they are also found in social groups that consist of a dominant male and one to five subordinate females, often related to each other (Macdonald 1983).

Enhancing the social richness of the housing 
Ahola, L. et al. Effects of group size and space allocation in silver for cubs

environment does not include only the companionship of conspecifics but also an enlargement of the total living space for the members of the group if complying with the minimum space requirements for the species (e.g. $1.2 \mathrm{~m}^{2}$ for a pair of farmed juvenile foxes after weaning and an additional $0.5 \mathrm{~m}^{2}$ for each additional animal, European Convention 1999). This enlargement of the total space, further, provides the animals with an increased opportunity for physical exercise.

In farmed silver foxes, only a few experiments in cage environment have been conducted to investigate whether a housing system with more than one or two foxes in the same living area could represent a potential housing system for this species. Bakken et al. (1994) report a study where one, two, four or eight silver foxes were housed with a density of one animal per $\mathrm{m}^{2}$. No data was available on whether the foxes within the group were related to each other. In larger groups, there were some problems with animals being bitten. On the other hand, group housed foxes had a better growth rate and were more active. In two other studies (Ahola et al. 1996, Ahola and Mononen 2002), silver foxes were housed in family groups, e.g. a vixen together with its cubs and compared to housing silver foxes in sibling pairs. No clear effects of the housing system on body weight of the cubs were found but the family-housed foxes had more injuries than the foxes housed in pairs, especially when space allocation for the individuals within the group was diminished (Ahola et al. 1996). It was also noted that aggressive behaviour between the family members and the number of cages occupied simultaneously by the family members increased with advancing autumn, i.e. the foxes tended to stay apart from one another (Ahola and Mononen 2002).

The present study focused on exploring the behavioural, physiological and production-related effects of different group sizes (one, two or four fox cubs per group) and different space allocations ( 0.6 or $1.2 \mathrm{~m}^{2}$ per animal) in farmed silver fox cubs housed in a cage environment.

\section{Material and methods}

The approval to conduct the present study was issued by the Institutional Animal Care and Use Committee of the University of Kuopio (Licence number 00-36).

\section{Animals and cage constructions}

A total of 98 silver fox cubs from 35 vixens were included in the study. The cubs were born in traditional fox cages $(115 \times 105 \times 70 \mathrm{~cm}, \mathrm{~L} \times \mathrm{W} \times$ $\mathrm{H})$ in April-May. At the time of weaning, i.e. when the cubs were approximately eight weeks old, they were divided into five different housing systems with different group sizes $(1,2$ or 4 animals per group) and different space allocations $\left(1.2 \mathrm{~m}^{2}\right.$ per animal, large, $\mathrm{L}$ and $0.6 \mathrm{~m}^{2}$, small, $\mathrm{S})$.

The housing systems were: 1) a male or a female cub (siblings) housed singly in a traditional cage $\left(1.2 \mathrm{~m}^{2}\right.$ per animal, L1), 2) a malefemale sibling pair housed in a traditional cage $\left(0.6 \mathrm{~m}^{2}\right.$ per animal, $\left.\left.\mathrm{S} 2\right), 3\right)$ a male-female sibling pair housed in two traditional cages connected together by an opening $(20 \times 20 \mathrm{~cm}, \mathrm{~W} \times$ $\mathrm{H})$ through the walls between the adjacent cages $\left(1.2 \mathrm{~m}^{2}\right.$ per animal, L2), 4) two male and two female siblings housed in two traditional cages connected together by openings $\left(0.6 \mathrm{~m}^{2}\right.$ per animal, S4) and 5) two male and two female siblings housed in four traditional cages connected together by openings $\left(1.2 \mathrm{~m}^{2}\right.$ per animal, L4). Each of the cages were furnished with a resting platform $(105 \times 30 \mathrm{~cm}, \mathrm{~L} \times \mathrm{W}, 25 \mathrm{~cm}$ from the cage ceiling) and a feeding tray.

The housing units were located in an outdoor fur shed with two cage rows. The number of each housing system was seven. Therefore, seven male and seven female cubs (siblings, from seven vixens) were housed singly in 14 traditional cages, 14 sibling pairs (from 14 vixens) were housed either in a system comprising of one cage (seven pairs) or of two cages (seven pairs), and 14 sibling quartets (from 14 vixens) were housed 
Vol. 11 (2002): 185-197.

either in a system comprising of two cages (seven quartets) or of four cages (seven quartets).

The animals were fed, according to the recommendations given by The Finnish Fur Breeders' Association, on fresh fur animal feed twice a day until late September, thereafter once a day. The daily feed portion per animal was the same for each group. There was one feeding tray in each traditional $\left(1.2 \mathrm{~m}^{2}\right)$ cage. In groups comprising of one traditional cage (L1 and S2) feed was delivered onto the only feeding tray. In groups comprising of two (L2 and S4) or four cages (L4) feed was delivered evenly onto two or four feeding trays, respectively.

\section{Measured parameters}

Each housing unit was video-recorded for $24 \mathrm{~h}$ in mid-August, at the beginning of October and at the beginning of December, as described in Ahola et al. (2001). Dim red bulbs (25 W) and fluorescent lamps $(38 \mathrm{~W})$ covered with red plastic film were used to provide dim light for the video-recordings. The behaviour of the animals was analysed from the videotapes using instantaneous sampling with a 5-min sampling interval (Martin and Bateson 1993), i.e. each of the cameras used recorded the behaviour of the animals in one unit approximately for 50-seconds giving 12 behavioural samples per each housing unit per one hour. The behavioural categories for the cubs were 1) active, i.e. moving, standing or sitting and 2) resting, i.e. lying awake or asleep. The activity of the animals was determined separately for the morning hours (0000-0800), working hours (0800-1600) and evening hours (1600-0000).

The extent of the use of available cages (L2, S4, L4) and resting platforms were also determined. Group preference index (GPI) for 24-h days in August, October and December was calculated for the groups S2, L2, S4 and L4 according to Gattermann (1990). GPI is a comparative value of a preference for staying in groups computed from the paired relations occurring in a group and ranges from $0 \%$ (all the animals within a housing unit singly, i.e. not touching each other) to $100 \%$ (all the animals within a housing unit together, touching each other).

The occurrence of locomotor stereotyped behaviour (i.e. repeated pacing or jumping along the cage wall without any obvious goal or function and performed without the neighbour, duration more than 5 seconds) was monitored from the December video-recordings.

The feeding test (see Rekilä 1999) was performed for the foxes in mid-August, late August, late September, late October and late November. To be able to recognise individual foxes they were painted with colorants on furs a day before the test. In the test, the experimenter presented feed on the feeding tray. The feed was placed on the only tray $(\mathrm{L} 1, \mathrm{~S} 2)$, on the tray of the first cage (L2, S4) and on the second cage of the cage system (L4). During the test, the experimenter stayed in the front of the cage (approximately $0.5 \mathrm{~m}$ from the cage wall) for $60 \mathrm{sec}$ and recorded the individuals that were eating during the test.

In late October, a 24-h urine was collected from all the housing units, i.e. 42 urine samples were obtained. The samples were stored at $-20^{\circ} \mathrm{C}$ until analysis for cortisol and creatinine. The cortisol concentration $\left(\mathrm{nmol} \mathrm{l}^{-1}\right)$ of the samples was analysed by a competitive immunoassay technique (Coat-A-Count Cortisol Assay by Diagnostic Products Corporation, Los Angeles, CA). The concentration of creatinine $\left(\mathrm{nmol} \mathrm{l}^{-1}\right)$ was analysed in the University Hospital of Kuopio (Finland) by kinetic Jaffe's reaction. Due to the variation in the dilution of urine, the content of cortisol in the urine was expressed as the cortisol-creatinine ratio (C:C) (Novak and Drewsen 1989, Lasley and Kirkpatric 1991). In group L1, the urine samples of the siblings housed in different cages were analysed separately but the results were thereafter pooled together.

Stress-induced hyperthermia (SIH) test was performed in the beginning of November. Due to the diurnal variation in foxes' deep body temperature with lowest temperatures between 0700-1600 (Moe and Bakken 1997), the SIH test was performed between 0800-1500. In the test, a set of animals including all the experimental 
Ahola, L. et al. Effects of group size and space allocation in silver for cubs

housing systems (i.e. 14 animals) situating in one side of the aisle of the shed were successively caught from their home cages. The time needed for catching the animal (TIME) was recorded. TIME was determined as the time lapsed from the moment when humans entered the shed for the first time to carry out the SIH test to the time the cub was captured in its cage. The rectal temperature $\left(\mathrm{T}_{\mathrm{re}}\right)$ at the beginning of the test $\left(\mathrm{T}_{\mathrm{re} 0}\right)$ was measured with a digital thermometer (Omron). Thereafter the fox was placed into a small wire mesh cage $(70 \times 35 \times 35 \mathrm{~cm}, \mathrm{~L} \times \mathrm{W} \times \mathrm{H})$ situated inside the shed for $35 \mathrm{~min}$. $\mathrm{T}_{\mathrm{re}}$ was measured again $\left(\mathrm{T}_{\text {re35 }}\right)$ to obtain the maximum $\mathrm{SIH}$ (Moe and Bakken 1997). SIH was calculated as $\mathrm{T}_{\mathrm{re35}}-\mathrm{T}_{\mathrm{re0}}$. Only one or two sets of animals were tested during one day. When two sets were tested during a day the animals tested situated in the shed some 12 meters apart from each other, and the animals in the set tested later were not disturbed by humans before the SIH test.

At pelting time in January, the foxes were caught and injected i.m. with ACTH (0.3 mg per animal synthetic $\mathrm{ACTH}_{1-24}$, Synacthen Depot, Ciba). The foxes were placed alone into a smaller cage $(70 \times 35 \times 35 \mathrm{~cm}, \mathrm{~L} \times \mathrm{W} \times \mathrm{H})$, and $2 \mathrm{~h}$ after the injection they were euthanized according to the methods recommended by the Standing Committee of the European Convention for the Protection of Animals Kept for Farming Purposes (European Convention 1999) by electrocution. Blood samples were drawn with cardiac puncture. The serum cortisol level $\left(\mathrm{nmol} \mathrm{l}^{-1}\right)$, as a maximum response to ACTH administration (Fraser and Broom 1990, Broom and Johnson 1993, Terlouw et al. 1997, Ahola et al. 2000, 2001), was analysed by a competitive immunoassay technique (Coat-A-Count Cortisol Assay by Diagnostic Products Corporation, Los Angeles, CA).

Body mass of the animals was monitored before pelting. After pelting, both adrenals, heart, and gastrocnemius muscle (GAST) from the left hindlimb were removed, cleaned and weighed. GAST samples were frozen in liquid nitrogen and stored at $-70^{\circ} \mathrm{C}$ until assayed. Succinatedehydrogenase $(\mathrm{SDH})$ activity $(\mu \mathrm{mol}$ substrate utilised $\cdot \mathrm{mg}$ protein ${ }^{-1} \cdot \mathrm{min}^{-1}$ at $37^{\circ} \mathrm{C}$ ) was determined according to the procedure of Pennington (1961) as described in Ahola et al. (2000). Left tibias were cleaned from muscles and mechanical properties of the tibias were determined, using a three-point bending test with Lloyd Instrumental Testing Machine in Jokioinen at the Agrifood Research Finland, as described in Ahola et al. (2000).

The number of bite wounds from the leather side of the skins was monitored. Professional fur graders at the Finnish Fur Sales Ltd (Helsinki, Finland) evaluated the quality of the furs using a 10-point scale (1: poorest, 10: best). The length of dry skins was measured one week after pelting.

\section{Statistical analysis}

Since the siblings in the housing units with more than one animal (S2, L2, S4, L4) were not individually recognised from the videotapes, activity, use of available cages and platforms as well as locomotor stereotyped behaviour of the animals was expressed as the mean value of the siblings in each unit. Therefore, the number of cases in each housing system was seven with regard to the behavioural data, except for the results from the feeding tests where data from individual animals was used. In group L1 the behavioural (except the feeding tests) as well as the urinary cortisol-creatinine ratio data of the male and the female sibling housed in different cages were pooled together. Therefore, there were seven cases in each housing system also for the urinary cortisol-creatinine ratio. Furthermore, since each housing unit with more than one animal comprised of cubs from the same litter (i.e. not independent of each other) the mean values of the other measured physiological parameters (body mass, SIH, serum cortisol level after ACTH administration, the masses of adrenals, heart and GAST, SDH-activity of the GAST, breaking force of tibia) and the mean quality scores of furs as well as the mean number of bite wounds within each housing unit, sepa- 
Vol. 11 (2002): 185-197.

rately for male and female cubs, were used in statistical analyses (Martin and Bateson 1993). Therefore, the number of cases in each housing system was seven for both males and females with regard to the physiological (except the cortisol-creatinine ratio) and fur quality data.

The General Linear Model (GLM) for repeated measures was used to analyse differences between the five housing systems in activity levels, in the use of available cages and resting platforms and in GPI. The preference for the available cages in August, October and December in groups L2, S4 and L4 was tested with a random $50 \%$ by Paired Samples T-test (in groups L 2 and S4 the first vs. the second cage, in group L4 the two first cages vs. the two last cages combined). Since the mass parameters (heart, adrenal and GAST masses) correlated well with the length of the dry skin in each of the five housing system, the GLM for univariate measures with dry skin length as a covariate was used to analyse the effects of the housing systems on these parameters, i.e. the masses were corrected for the effect of the animal's body size. Differences between the housing systems in body mass, SIH, serum cortisol level after ACTH administration, cortisol-creatinine ratio, SDH-activity of GAST and breaking force of tibias were analysed with the GLM for univariate measures. The results from the five feeding tests were analysed using Pearson Chi-Square test. Kruskal-Wallis test and Mann-Whitney test were used to evaluate the effects of group size and sex or space allocation, respectively, on the quality scores of the furs and on the incidence of bite wounds as well as on the incidence of stereotyped behaviour.

All results have been expressed as mean \pm SD. P-values over 0.1 have been considered as non-significant (NS).

\section{Results}

During the whole experiment, two foxes from group L1 were found dead (one female in midOctober, one male in late November) and the number of cases in group L1 was, therefore, decreased from seven to six. Furthermore, one male from group L4 had to be removed from its housing unit due to an ear mite infection in late October. In this housing unit the results were defined by the data obtained from the animals left in the unit (two females and one male).

No differences were found in the 24-h activity levels between different group sizes or different space allocations (Table 1). Group size of the housing unit affected significantly only the mean activity level during the three 8 -hour periods through the whole experiment: the cubs housed singly were, in general, most active during the working hours (0800-1600) whereas the cubs housed in pairs or in quartets were more active during the evening hours (1600-0000). In general, the daily activity level was constant from August till December. The activity of the cubs was lowest during the morning hours, with decreasing activity levels during the evening hours from August till December.

In groups with more than one cage available (L2, S4 and L4), the cubs preferred to use the cage (L2, S4) or the two cages (L4) nearest to the door from which the humans normally entered the shed than the cage/cages further back (Fig. 1). No significant differences in the preference for these cages between the housing systems and between the months were revealed.

The extent of the use of the resting platforms decreased from August till December (Fig. 2). The use of platforms through the whole experiment increased with increasing group size and with increasing space allocation.

In groups S2 and L2, GPI did not change with advancing time (Fig. 3). In groups S4 and L4, GPI decreased with advancing autumn, i.e. the cubs within the quartets were more and more apart from each other when they grew older. Space allocation had no effect on GPI in the pair housed cubs. In quartets, GPI was significantly lower when the foxes were given more space.

There were no differences between the males and females in eating behaviour during the five feeding tests performed during the growing season. Therefore, the feeding test results from 
Ahola, L. et al. Effects of group size and space allocation in silver for cubs

Table 1. Total 24-h activity (total, \% of time) and activity during the morning (0000-0800), working (0800-1600) and evening hours (1600-0000) in the silver fox cubs in five experimental groups.

\begin{tabular}{|c|c|c|c|c|c|}
\hline & L1 & $\mathrm{S} 2$ & $\mathrm{~L} 2$ & S4 & L4 \\
\hline \multicolumn{6}{|l|}{ August } \\
\hline 0000-0800 & $15 \pm 3$ & $18 \pm 8$ & $25 \pm 10$ & $22 \pm 6$ & $24 \pm 11$ \\
\hline 0800-1600 & $36 \pm 5$ & $31 \pm 7$ & $23 \pm 2$ & $26 \pm 5$ & $24 \pm 2$ \\
\hline $1600-0000$ & $39 \pm 8$ & $43 \pm 9$ & $34 \pm 8$ & $38 \pm 4$ & $37 \pm 6$ \\
\hline total & $30 \pm 3$ & $30 \pm 3$ & $28 \pm 3$ & $28 \pm 3$ & $28 \pm 3$ \\
\hline \multicolumn{6}{|l|}{ October } \\
\hline 0000-0800 & $19 \pm 5$ & $22 \pm 9$ & $24 \pm 7$ & $24 \pm 7$ & $21 \pm 9$ \\
\hline 0800-1600 & $34 \pm 9$ & $25 \pm 6$ & $23 \pm 7$ & $26 \pm 7$ & $21 \pm 9$ \\
\hline $1600-0000$ & $36 \pm 8$ & $36 \pm 5$ & $30 \pm 6$ & $34 \pm 5$ & $39 \pm 8$ \\
\hline total & $30 \pm 4$ & $28 \pm 5$ & $26 \pm 2$ & $28 \pm 3$ & $27 \pm 5$ \\
\hline \multicolumn{6}{|l|}{ December } \\
\hline 0000-0800 & $16 \pm 6$ & $12 \pm 8$ & $15 \pm 7$ & $16 \pm 7$ & $14 \pm 2$ \\
\hline 0800-1600 & $42 \pm 7$ & $42 \pm 7$ & $37 \pm 8$ & $36 \pm 8$ & $37 \pm 4$ \\
\hline $1600-0000$ & $29 \pm 11$ & $30 \pm 13$ & $28 \pm 9$ & $33 \pm 8$ & $34 \pm 10$ \\
\hline total & $29 \pm 3$ & $28 \pm 5$ & $27 \pm 5$ & $28 \pm 3$ & $28 \pm 3$ \\
\hline
\end{tabular}

$\mathrm{L} 1$ = singly housed with $1.2 \mathrm{~m}^{2}$ per animal, $\mathrm{S} 2=$ pair housed with $0.6 \mathrm{~m}^{2}$ per animal, $\mathrm{L} 2=$ pair housed with $1.2 \mathrm{~m}^{2}$ per animal, S4 = quartet housed with $0.6 \mathrm{~m}^{2}$ per animal, $\mathrm{L} 4=$ quartet housed with $1.2 \mathrm{~m}^{2}$ per animal.

Significance levels: group size NS, space allocation NS, hours $\mathrm{P}<0.001$, month NS. Interaction month $\times$ hours $\mathrm{P}<0.001$, hours $\times$ group size $\mathrm{P}<0.001$, other interactions non-significant.

males and females were pooled together. There were no differences in the percentage of animals never coming to eat during the five feeding tests between the measured space allocations whereas the percentage of animals never coming to eat during the tests was highest in the foxes housed in quartets (Table 2). From the five separate feeding tests, no significant differences were revealed between different space allocations. Group size affected only the test performed in late October when the percentage of animals eating during the test was significantly lower in quartets than in other housing systems (percentage of foxes eating during the test $39 \%, 46 \%$ and $20 \%$ in singles, pairs and quartets, respectively, $\mathrm{P}<0.05$ ).

In December, the cubs housed singly spent

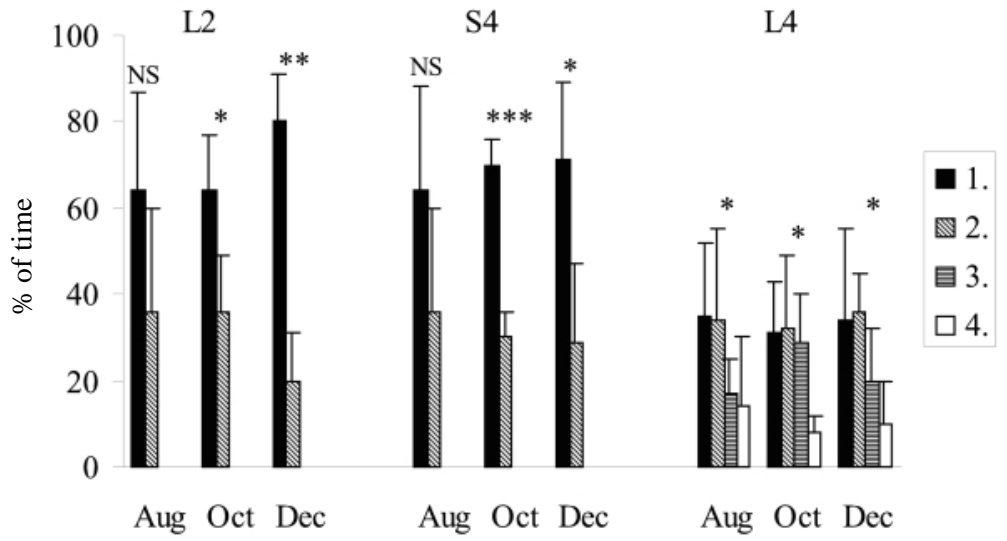

Fig. 1. Use of different cages $(\%$ of time spent in cages 1.-4., 1. = the cage nearest to the door humans normally entered the shed) in housing systems with more than one cage available in silver fox cubs. $\mathrm{L} 2$ = pair housed with $1.2 \mathrm{~m}^{2}$ per animal, $\mathrm{S} 4=$ quartet housed with $0.6 \mathrm{~m}^{2}$ per animal, $\mathrm{L} 4=$ quartet housed with $1.2 \mathrm{~m}^{2}$ per animal. Significance levels (L2, S4: cage 1. vs. $50 \%$, L4: cages 1 . and 2. vs. $50 \%$ ): NS P $>0.1, * \mathrm{P}<0.05$, $* * \mathrm{P}<0.01, * * * \mathrm{P}<0.001$. 
Vol. 11 (2002): 185-197.

significantly more time in locomotor stereotyped behaviour than the cubs housed in pairs or in quartets (Table 2). Space allocation had no effect on stereotyped behaviour.

Because no sex differences in TIME, $\mathrm{T}_{\text {re } 0}$, $\mathrm{T}_{\text {re35 }}$ and the change in rectal temperatures were revealed the results from males and females were pooled together. TIME, $\mathrm{T}_{\mathrm{re} 0}, \mathrm{~T}_{\mathrm{re} 35}$ and the change in rectal temperature were not affected by either group size or space allocation (Table 2).

No significant effects of group size and space allocation were found on urinary cortisol-creatinine ratio, serum cortisol level after ACTH administration and mass of adrenals (Table 2). A sex difference was evident in the mass of adrenals even though this mass was corrected with the dry skin length as a covariate for the effect of body size.

The body mass of the cubs was not affected by either group size or space allocation (Table 2). In general, the males were significantly heavier than the females.

A sex difference existed in the masses of heart and GAST as well as in the breaking force of tibia (Table 2). The mass of heart was influenced by space allocation: the cubs in housing systems with a larger area per animal had heavier hearts than the cubs with $0.6 \mathrm{~m}^{2}$ per animal. Furthermore, the animals in groups of four showed a tendency to have lighter hearts than the animals

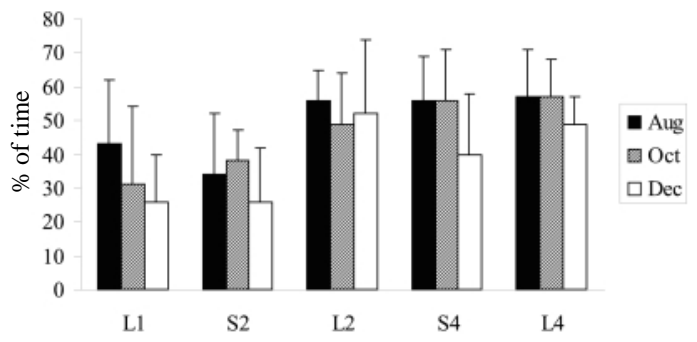

Fig. 2. Use of available resting platforms (\% of time spent on platform/platforms) in five different housing systems. $\mathrm{L} 1=$ singly housed with $1.2 \mathrm{~m}^{2}$ per animal, $\mathrm{S} 2=$ pair housed with $0.6 \mathrm{~m}^{2}$ per animal, L2 = pair housed with $1.2 \mathrm{~m}^{2}$ per animal, $\mathrm{S} 4=$ quartet housed with $0.6 \mathrm{~m}^{2}$ per animal, $\mathrm{L} 4=$ quartet housed with $1.2 \mathrm{~m}^{2}$ per animal. Significance levels (GLM for repeated measures): month $\mathrm{P}<0.001$, group size $\mathrm{P}<0.01$, space allocation $\mathrm{P}<0.05$. No significant interactions.

housed either singly or in pairs. Neither group size nor space allocation had any effects on the mass of GAST, SDH-activity of GAST and on the breaking force of tibia.

The quality of furs (quality scores in males: $7.3 \pm 0.8,6.9 \pm 1.5,6.9 \pm 1.5,4.9 \pm 1.8$ and 6.4 \pm 1.1 , in females: $7.0 \pm 1.1,6.3 \pm 0.5,6.1 \pm 1.9$, $3.6 \pm 1.4$ and $5.4 \pm 1.3$ in groups L1, S2, L2, S4 and L4, respectively) decreased with increasing group size $(\mathrm{P}<0.001)$ and with decreasing space allocation $(P<0.05)$. In general, males had better fur quality than females $(\mathrm{P}<0.05)$. In males,

Fig. 3. Group preference index (\%, above the bars) and occurrence of different group compositions (\% of time) in silver fox cubs in August, October and December. S2 = pair housed with $0.6 \mathrm{~m}^{2}$ per animal, L2 = pair housed with $1.2 \mathrm{~m}^{2}$ per animal, S4 = quartet housed with $0.6 \mathrm{~m}^{2}$ per animal, L4 = quartet housed with $1.2 \mathrm{~m}^{2}$ per animal. Horizontal lines: all singly, grids: one pair and two singly, open: two pairs, diagonal lines: one singly and one trio, solid: all together. Significance levels for GPI: S2 month NS, L2

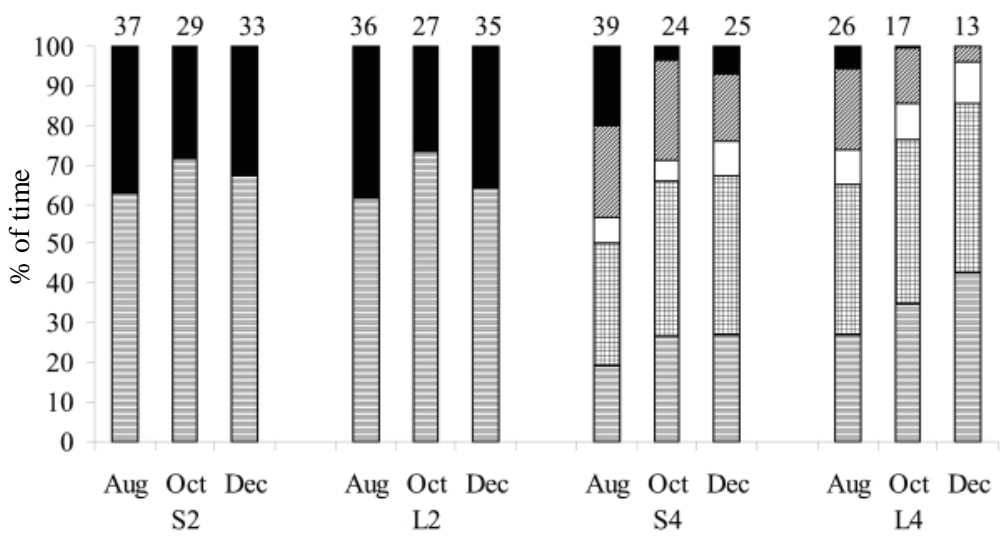
month NS, S4 month P < 0.01, L4 month $\mathrm{P}<0.01$, S2 vs. L2 space allocation NS, S4 vs. L4 space allocation $\mathrm{P}<0.01$. No significant interactions. 
Ahola, L. et al. Effects of group size and space allocation in silver for cubs

\begin{tabular}{|c|c|c|c|c|}
\hline & 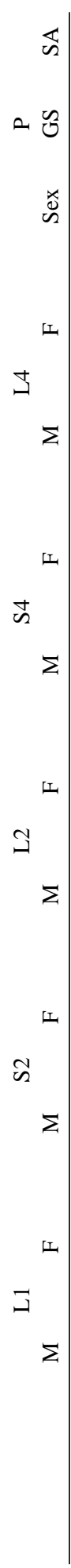 & 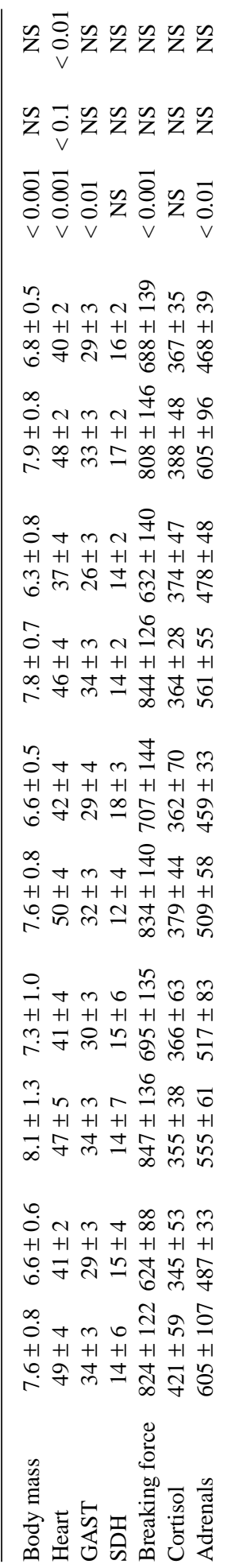 & 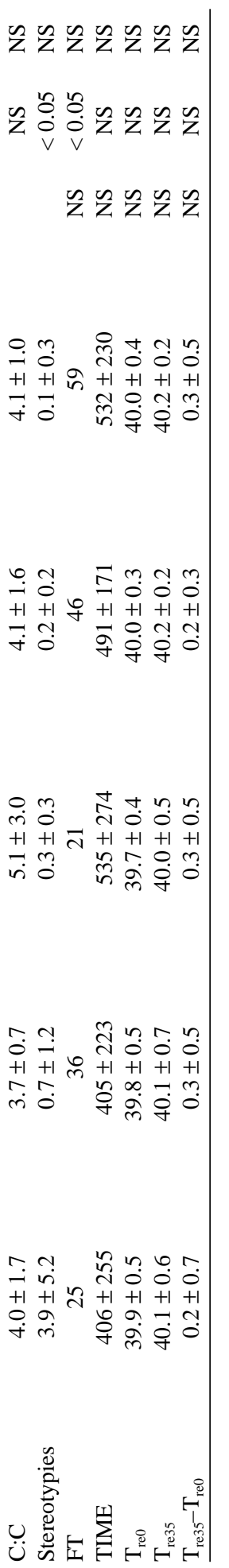 & 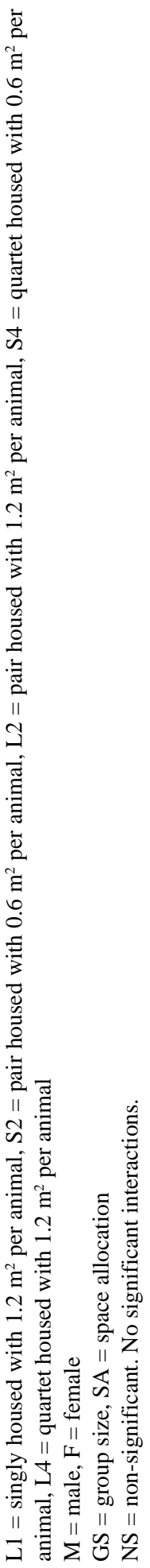 \\
\hline
\end{tabular}


Vol. 11 (2002): 185-197.

neither group size nor space allocation had any effects on the number of bite wounds (L1: $0.8 \pm$ $0.8, \mathrm{~S} 2: 1.1 \pm 1.8, \mathrm{~L} 2: 1.3 \pm 2.1, \mathrm{~S} 4: 0.3 \pm 0.6$ and L4: $0.9 \pm 1.4$, group size NS, space allocation NS). In females, the number of bite wounds was lower in the cubs that were given larger space allocation while group size had no effects on the incidence of bite wounds (L1: $1.0 \pm 1.7$, S2: $2.3 \pm 2.0, \mathrm{~L} 2: 0.3 \pm 0.5, \mathrm{~S} 4: 1.6 \pm 1.4$ and L4: $1.4 \pm 1.4$, group size NS, space allocation $\mathrm{P}<0.05)$. No significant sex difference in the number of bite wounds was revealed.

\section{Discussion}

Earlier studies on canids kept for laboratory or farming purposes (e.g. dogs, foxes) exploring the linkage between increased available space or increased number of animals within a housing unit and activity level have led to contradictory conclusions. As the amount of space available increases, the activity level of the animals has either increased (dog: Hetts et al. 1992), remained constant (raccoon dog: Korhonen and Harri 1988), or decreased (dog: Hughes et al. 1989). Increasing the number of animals within a housing unit, which usually means also increasing the total available area for the members of the group, has typically increased the activity level of the animals (dog: Hubrecht et al. 1992; silver fox: Bakken et al. 1994, Ahola et al. 2000, but see dog: Hetts et al. 1992). In the present study, neither increasing space allocation $\left(0.6 \mathrm{~m}^{2}\right.$ vs. $1.2 \mathrm{~m}^{2}$ ) nor increasing the number of animals within a housing unit (one vs. two vs. four) evoked any differences in activity levels of the animals. However, the mass of heart was greater in the cubs that had $1.2 \mathrm{~m}^{2}$ per animal compared to the cubs that had only $0.6 \mathrm{~m}^{2}$, perhaps indicating that larger space allocation enables the animals to exercise more. This result is, however, not unambiguous in regard of the increased space because the hearts tended to be lighter in the cubs housed in quartets with total area avail- able for the cubs being 2.4 or $4.8 \mathrm{~m}^{2}$ than in the cubs housed either singly or in pairs with 1.2 or $2.4 \mathrm{~m}^{2}$ available area. The reason for this result may be that, even though in theory an animal could have exercised more in the larger area, the possibility for this was turned down by the cage mates in the quartets. However, all the results of the other exercise-related parameters (i.e. mass of GAST as well as SDH-activity of GAST and the breaking force of tibia) support the conclusion that increasing space from $1.2 \mathrm{~m}^{2}$ to $4.8 \mathrm{~m}^{2}$ does not necessarily alter the rate of exercise in silver fox cubs.

The result that the cubs housed singly were more active during the working hours than the cubs housed with their littermates may be due to the absence of conspecifics and, therefore, these singly housed cubs were perhaps more bonded to human activity. The impact of the presence of humans on activity has earlier been documented in singly housed laboratory dogs (Hite et al. 1977, Hughes et al. 1989). That the cubs housed in quartets were more tied with the activities of their cage mates became obvious also during the feeding tests: significantly less animals were eating during the five feeding tests in quartets than in other housing systems. This result would suggest that the foxes housed in quartets were experiencing human proximity as more aversive than the other foxes, as the feeding test is validated to measure animals' fear responses towards human (see Rekilä 1999). However, the SIH test (see Moe and Bakken 1997) indicated that there were no differences in fear responses towards human between the foxes housed in different group sizes or space allocations. Therefore, the present results revealed that the feeding test may also indicate the effects of group housing and of social tension within a group on the behaviour of the foxes rather than only the level of fear towards humans, as earlier shown in farmed blue foxes housed in sibling groups (Ahola et al. 2002).

The cubs that had more than one cage available used their area unevenly. Most often the animals were in the cage (groups L2 and S4) or in the two cages (group L4) situated nearest to 
Ahola, L. et al. Effects of group size and space allocation in silver for cubs

the door that was used by humans when they entered the shed. The same result has earlier been reported in dogs that did not utilise the additional floor space which was three times the area of the smaller cage size but preferred to stay most of their time in the front parts of their cage (Hite et al. 1977). This preference for the foreparts of the cage area may be due to the general inquisitiveness of the animals towards human activity or the animals' tendency to ensure that there is some space for escape from a sudden appearance of humans. In any case, the foxes ability to choose between some more or less favourable areas in their cage systems may have promoted their sense of control which, in turn, may enhance the welfare of animals (e.g. Fraser and Broom 1990, Broom and Johnson 1993, Pedersen and Jeppesen 1998).

Although the group members were often in a single cage they were not huddled together all the time. The resting platforms in each cage enabled the animals within a housing unit to keep their own space in one cage either on the floor of the cage or on the resting platform. The tendency to be apart from the littermates with the passing of autumn was seen especially in group L4 where, on the one hand, the situations that the cubs were in tight trios or quartets became more and more rare and, on the other hand, the cubs' preference for being alone increased. This phenomenon of loosing bonds between the littermates is well known from the wild red foxes during the autumn, at the time of dispersion (Bekoff 1977). In the wild, red foxes may or may not disperse, and eventually live in social units with only one male and 1-5 females, often related to each other (Macdonald 1983). Therefore, it may be that for the pair housed cubs there was no such reason to evade each other during the late autumn as there was in quartets with two males. Other possible explanation is that the increased space $\left(4.8 \mathrm{~m}^{2}\right.$ in group L4) allowed the group members to be more apart from each other. This explanation is supported by the finding that group housed dogs placed more distance between themselves when given larger cages (Bebak and Beck 1993).
The present study did not reveal differences in the serum cortisol level after ACTH administration, adrenal mass or urinary cortisol-creatinine ratio between the five housing systems, indicating that no housing system examined here was better or worse than any of the other in terms of the measured parameters. The same result, i.e. that cage size or exercise level or combination of these two has little or no effect on the physiological indicators of stress, has earlier been reported in dogs (Campbell et al. 1988, Clark et al. 1991). The social environment an animal lives in, in contrast, has been found to have effects on the incidence of stereotyped behaviour. Dogs in social isolation exhibited the greatest number of bizarre movements (Hetts et al. 1992) and spent considerably more time in repetitive behaviour (Hubrecht et al. 1992). When dogs were transferred from group conditions into smaller, individual housing systems they showed lower postures, signs of repetitive behaviour and autogrooming (Beerda et al. 1999). In the present study, only locomotor stereotyped behaviour performed without the neighbour was monitored. This was due to the ambivalence about which of the behaviours measured in earlier studies and considered to represent stereotyped behaviour actually meet the criteria of stereotypes (Wikman et al. 1999). The results from the present study show that the amount of locomotor stereotyped behaviour in the cubs housed either in pairs or in quartets was similar to that earlier reported in singly housed silver foxes $(0.3 \%$ of a 24-h day, Wikman et al. 1999). In contrast to earlier results by Wikman et al. (1999), in the present study the singly housed cubs performed locomotor stereotyped behaviour almost $4 \%$ of the time. One reason for the higher occurrence of stereotyped behaviour in the present study may be that stereotyped behaviour develops with time (see Mason 1991), and in the study of Wikman et al. the age of the animals was 4-5 months whereas in the present study the foxes were 7-8 months old. The other reason may be that in the present study the cubs were put straight after weaning singly in their experimental cage, whereas in Wikman et al. (1999) and according 
Vol. 11 (2002): 185-197.

to normal farming practice the siblings after weaning are first kept in groups and only after some time separated into pairs or singles. Whatever the reason, and although there were no differences in the present study between the housing systems in the HPA-axis activity, the occurrence of stereotyped behaviour in group L1 suggests that some cubs housed singly (not all the animals performed this behaviour: in December, three out of six male cubs accounted for $99 \%$ and two out of six female cubs accounted for $89 \%$ of the total amount of stereotypes in singly housed males and females, respectively) may have had poorer welfare, e.g. they were frustrated because did not have any cage mates.

Although the physiological stress indicators measured or the body mass of the animals were not affected by group size and space allocation, these factors did affect the quality of the furs and the incidence of bite wounds. The quality of the furs decreased with increasing group size and with decreasing space allocation, resulting in poor quality furs especially in the group with four cubs housed with $0.6 \mathrm{~m}^{2}$ per animal (group S4). The reason for this may be that in group S4 the combination of group size and space allocation resulted in crowded conditions, which can affect the performance of animals more than if only one of these factors is changing in the housing conditions (see Fraser and Broom 1990). Space allocation as such had an effect on the incidence of bite wounds in the female cubs. It seems obvious that females had difficulties in avoiding aggressive contacts with their cage mates when the foxes were given less space per individual.

\section{Conclusion}

The cubs that were separated from their mother and siblings straight into single living performed significantly more locomotor stereotyped behaviours than the cubs housed in pairs and in quartets. This result indicates that a possibility for social behaviour is important for the welfare of young silver fox cubs. However, at the time of foxes' natural dispersal, the cubs housed in quartets tended to stay apart from each other possibly due to increased within-group social tension. Therefore, to enhance the welfare of silver fox cubs, the group housed cubs should possibly be separated in later autumn to live in pairs. Space allocation as such had only minor effects on the physiology and behaviour of the cubs. However, the effect of decreased space allocation was revealed as decreased fur quality and as increased biting injuries in female cubs.

Acknowledgements. This study was supported by The Research Council for the Environment and Natural Resources of the Academy of Finland and by the Finnish Fur Breeders'Association (FFBA). We are grateful to Mrs. Maija Miskala for her skilful assistance during the field experiments. We also thank Mr Tuomo Tupasela, M.Sc., for arranging the measurement of the mechanical properties of tibias.

\section{References}

Ahola, L., Harri, M., Kasanen, S., Mononen, J. \& Pyykönen, T. 2000. Effect of family housing of farmed silver foxes (Vulpes vulpes) in outdoor enclosures on some behavioural and physiological parameters. Canadian Journal of Animal Science 80: 427-434.

Ahola, L., Harri, M., Mononen, J., Pyykönen, T. \& Kasanen, S. 2001. Welfare of farmed silver foxes (Vulpes vulpes) housed in sibling groups in large outdoor enclosures. Canadian Journal of Animal Science 81: 435-440.

Ahola, L., Harri, M., Mononen, J., Pyykönen, T. \& Kasanen, S. 2002. Effects of group size and early han- dling on some behavioural and physiological welfare parameters in farmed blue foxes. Agricultural and Food Science in Finland 11: 25-35.

Ahola, L., Harri, M., Mononen, J. \& Rekilä, T. 1996. Family housing of blue and silver foxes in a row cage system. In: Frindt, A. \& Brzozowski, M. (eds.). Proceedings from the VIth International Scientific Congress in Fur Animal Production. 21-23 August 1996, Warsaw, Poland. p. 71-76.

Ahola, L. \& Mononen, J. 2002. Family break-up in farmed silver foxes (Vulpes vulpes) housed in enlarged cage systems as families. Acta Ethologica 4: 125-127. 
Ahola, L. et al. Effects of group size and space allocation in silver for cubs

Bakken, M., Braastad, B.O., Harri, M., Jeppesen, L.L. \& Pedersen, V. 1994. Production conditions, behaviour and welfare of farm foxes. Scientifur 18: 233-248.

Bebak, J. \& Beck, A.M. 1993. The effect of cage size on play and aggression between dogs in purpose-bred beagles. Laboratory Animal Science 43: 457-459.

Beerda, B., Schilder, M.B.H., van Hooff, J.A.R.A.M., de Vries, H.W. \& Mol, J.A. 1999. Chronic stress in dogs subjected to social and spatial restriction. I. Behavioral responses. Physiology \& Behavior 66: 233-242.

Bekoff, M. 1977. Mammalian dispersal and the ontogeny of individual behavioral phenotypes. American Naturalist 111: 715-732.

Broom, D. \& Johnson, K.G. 1993. Stress and animal welfare. $1^{\text {st }}$ ed. Chapman \& Hall, London, UK. 211 p.

Campbell, S.A., Hughes, H.C., Griffin, H.E., Landi, M.S. \& Mallon, F.M. 1988. Some effects of limited exercise on purpose-bred Beagles. American Journal of Veterinary Research 49: 1298-1301.

Cavallini, P. 1996. Variation in the social system of the red fox. Ethology Ecology \& Evolution 8: 323-342.

Clark, J.D., Calpin, J.P. \& Armstrong, R.B. 1991. Influence of type of enclosure on exercise fitness of dogs. American Journal of Veterinary Research 52: 10241028.

European Convention 1999. Standing committee of the European Convention for the protection of animals kept for farming purposes. Recommendation concerning fur animals. T-AP (96) 19.

Fraser, A.F. \& Broom, D.M. 1990. Farm animal behaviour and welfare. $3^{\text {rd }}$ ed. Baillière Tindall, London, UK. 437 p.

Gattermann, R. 1990. Verhaltensbiologisches Praktikum. VEB Gustav Fisher Verlag, Jena. 184 p.

Hetts, S., Clark, J.D., Calpin, J.P., Arnold, C.E. \& Mateo, J.M. 1992. Influence of housing conditions on beagle behaviour. Applied Animal Behaviour Science 34: 137-155.

Hite, M., Hanson, H.M., Rohidar, N.R., Conti, P.A. \& Mattis, P.A. 1977. Effect of cage size on patterns of activity and health of beagle dogs. Laboratory Animal Science 27: 60-64.

Hubrecht, R.C., Serpell, J.A. \& Poole, T.B. 1992. Correlated of pen size and housing conditions on the behaviour of kennelled dogs. Applied Animal Behaviour Science 34: 365-383.

Hughes, H.C., Cambell, S. \& Kenney, C. 1989. The effects of cage size and pair housing on exercise of beagle dogs. Laboratory Animal Science 39: 302305.

Korhonen, H. \& Harri, M. 1988. Effect of cage size on growth, feed intake, fur quality and activity pattern of farmed raccoon dogs. Zeitschrift für Versuchstierkunde 31: 49-54.

Lasley, B.L. \& Kirkpatric, J.F. 1991. Monitoring ovarian function in captive and free-ranging wildlife by means of urinary and fecal steroids. Journal of Zoo and Wildlife Medicine 22: 23-31.

Macdonald, D.W. 1983. The ecology of carnivore social behaviour. Nature 301: 379-384.

Martin, P. \& Bateson, P. 1993. Measuring behaviour, an introductory guide. $2^{\text {nd }}$ ed. University Press, Cambridge, UK. 222 p.

Mason, J.G. 1991. Stereotypies: a critical review. Animal Behaviour 41: 1015-1037.

Mendl, M. \& Newberry, R.C. 1997. Social conditions. In: Appleby, M.C. \& Hughes, B.O. (eds.). Animal Welfare. CAB International. p. 191-203.

Moe, R.O. \& Bakken, M. 1997. Effects of handling and physical restraint on rectal temperature, cortisol, glucose and leukocyte counts in the silver fox (Vulpes vulpes). Acta Veterinaria Scandinavica 38: 29-39.

Novak, M.A. \& Drewsen, K.H. 1989. Enriching the lives of captive primates. In: Segal, E.F. (ed.). Housing, care and psychological wellbeing of captive and laboratory primates. Park Ridge, NJ: Noyes Publications. p. $162-164$.

Pedersen, V. \& Jeppesen, L.L. 1998. Different cage sizes and effects on behaviour and physiology in farmed silver and blue foxes. Scientifur 22: 13-22.

Pennington, R.J. 1961. Biochemistry of dystrophic muscle. Mitochondrial succinate-tetrazolium reductase and adenosine triphosphatase. Biochemical Journal 80: 649-654.

Rekilä, T. 1999. Behavioural tests in welfare research of foxes. Kuopio University Publications C. Natural and Environmental Sciences 92: 1-52.

Terlouw, E.M.C., Schouten, W.G.P. \& Ladewig, J. 1997. Physiology. In: Appleby, M.C. \& Hughes, B.O. (eds.). Animal Welfare. CAB International, University Press, Cambridge, UK. p. 143-158.

Wikman, I., Mononen, J., Rekilä, T. \& Harri, M. 1999. Stereotyped behaviour in juvenile foxes. In: Bøe, K.E. et al. (eds.). Proceedings of the $33^{\text {rd }}$ International Congress of the International Society for Applied Ethology. 17-21 August 1999, Lillehammer, Norway. p. 109. 
Vol. 11 (2002): 185-197.

\section{SELOSTUS}

\section{Ryhmäkoon ja käytössä olevan tilan vaikutus tarhattujen hopeakettupentujen hyvinvointiin}

Leena Ahola, Jaakko Mononen, Teija Pyykönen, Maarit Mohaibes ja Teppo Rekilä Kuopion yliopisto ja MTT (Maa- ja elintarviketalouden tutkimuskeskus)

Tarhattuja hopeakettuja kasvatetaan vieroituksen jälkeen yleisimmin uros-naaraspareittain perinteisissä kettuhäkeissä. Kritiikki kasvatusmuotoa kohtaan ja kiinnostus tuotantoeläinten hyvinvointiin on lisännyt tarvetta etsiä vaihtoehtoisia kasvatusmuotoja tarhattaville turkiseläimille. Tässä työssä selvitettiin voidaanko tarhattujen hopeakettupentujen hyvinvointia parantaa rikastuttamalla perinteisiä kettujen kasvatusoloja sosiaalisella ja fyysisellä ympäristöllä.

Hopeakettupentuja kasvatettiin vieroituksen jälkeen yksittäin, pareittain tai neljän kettupennun ryhmissä. Tilaa ketuille annettiin $0,6 \mathrm{~m}^{2}$ tai $1,2 \mathrm{~m}^{2}$ eläintä kohti. Erilaisten kasvatusolojen vaikutusta hyvinvointiin selvitettiin määrittämällä hopeakettupentujen käyttäytymistä, fysiologiaa ja nahan laatua.
Saadut tulokset osoittivat, että mahdollisuus oleskella lajikumppaneiden kanssa on tärkeää nuorille hopeakettupennuille. Kettupentuja kannattaisikin ehkä kasvattaa sisarusryhmissä perinteistä tarhauskäytäntöä pidempään. Tilanne on kuitenkin hieman toinen vanhemmilla pennuilla. Hopeaketut näyttävät säilyttäneen luontaisen taipumuksensa erota perheenjäsenistään ensimmäisen syksyn aikana. Hopeakettupentujen hyvinvoinnin kannalta on kenties hyvä, että pennut myöhemmin syksyllä erotetaan sisaruksistaan elämään sisaruspareissa. Käytössä olevalla tilalla ei ollut kovin suurta merkitystä kettujen käyttäytymiselle ja fysiologialle. Tuotanto-ominaisuudet kuitenkin heikkenivät, kun tila pieneni $1,2 \mathrm{~m}^{2}$ :stä $0,6 \mathrm{~m}^{2}$ :iin kettua kohden. 